\title{
Zingiber officinale Rosc. essential oil, a review on its composition and bioactivity
}

\author{
Mohaddese Mahboubi®
}

\begin{abstract}
Zingiber officinale Rosc. is widely used as spice and medicinal plant in folk and traditional medicines. The aim of this study was to review the chemical composition and biological activities of $Z$. officinale (ginger) essential oil. Ginger oil is extracted from Z. officinale rhizomes, which its chemical composition influences from geographical region, extraction methods, freshness or dryness of rhizomes. The antibacterial, antifungal, analgesic, anti-inflammatory, anti-ulcer, immunomodulatory, relaxant, and warming effects of ginger oil have been confirmed in experimental and preclinical studies. The safety issues of ginger oils are well documented and are generally regarded as safe. Due to wide pharmacological effects of ginger oil, attention to ginger oil as an ingredient of natural formulations in management of gastrointestinal and respiratory diseases is valuable.
\end{abstract}

Keywords: Essential oil, Pharmacological effects, Zingiber officinale, Ginger

\section{Introduction}

Zingiber officinale Rosc. (ginger), as the member of Zingiberaceae family is widely used as spice or medicinal plant in folk and traditional medicines. The medicinal part of ginger is rhizomes, which are used in traditional medicine for treatment of wide range of ailments. In Ayurveda system, ginger and milk or water in the form of paste are used externally for treatment of infantile colic. The combination of ginger with honey is used for asthmatic bronchitis, cough, hiccups, and respiratory colds. In traditional Chinese system, fresh ginger is believed to have mild warm temper, while dried and roasted ones are regarded as warm and hot, respectively [1]. It is used for digestive ailments, and appetite disorders [2]. Ginger is used for digestive problems in western medicine. Henry VIII recommended the use of ginger for preventing the plague. The prepared bread with ginger by Greeks is consumed after meal as digestive aid [3]. Blood purifying, aphrodisiac, sex stimulants, appetizing, anti-flatulent, antispasmodic, anti-hemorrhoid, anti-vomiting, and anti-nausea effects of ginger are other traditional prospects [4]. Ginger rhizomes are containing fatty oils (3-6\%), proteins (9\%), carbohydrates $(60-70 \%)$, crude fiber (3-8\%), ash (8\%), water (9-12\%), and volatile oil (2-3\%). Nowadays,

Correspondence: mahboubi1357@yahoo.com; M_mahboubi@Tabibdaru.com Medicinal Plants Research Department, Research and Development, TabibDaru Pharmaceutical Company, Kashan, Iran ginger hydro-ethanol extracts are extensively used as analgesic, anti-inflammatory, anticancer, anti-diabetic, hepatoprotective, nephron-protective, and antioxidant agents [5], which has been the subject of many review articles [6-8]. The aim of this review article was to investigate the chemical composition of ginger essential oil and its pharmacological effects according to published literatures up to December 2017. The information was extracted from accessible international electronic databases (PubMed, Springer, Science Direct, Wiley and Google), and books (Persian or English), by key word of Zingiber officinalis essential oil or ginger.

\section{Chemical composition of ginger essential oil}

Ginger oil's yield is varying from 1.0 to $3 \%$, depending upon the source of rhizomes [9]. In addition to the essential oil's yields, the chemical compositions of ginger oils are affected from the source of rhizome, freshness or dryness and extraction methods. Due to importance of essential oil's yields and chemical compositions, these subjects were reviewed in this section (Table 1).

Investigation in research articles showed that Nigerian fresh ginger oil $(1.02 \% \mathrm{w} / \mathrm{v})$ was found to have $\beta$-zingiberene $(12.2 \%), 1,8$-cineole+limonene $+\beta$-phellandrene $(10.5 \%)$, geraniol (15\%), neral (8.9), $\beta$-bisabolene (5.6\%) and $\beta$-sesquiphellandrene (6.5\%), while its oil from dried rhizomes $(1.84 \% \mathrm{w} / \mathrm{v})$ had $\beta$-zingiberene 
Table 1 The chemical composition of Zingiber officinale essential oil from different geographical region

\begin{tabular}{|c|c|c|c|c|}
\hline Yield & Rhizomes & Components & Location & Ref \\
\hline 1.02 & Fresh & $\begin{array}{l}\beta \text {-zingiberene }(12.2 \%) \text {, geraniol }(15.0 \%) \text {, neral }(8.9 \%), \beta \text {-bisabolene } \\
(5.6 \%) \text { and } \beta \text {-sesquiphellandrene }(6.4 \%)\end{array}$ & Nigeria & [10] \\
\hline $1.84 \%$ & Dried & $\begin{array}{l}\beta \text {-zingiberene (28.1\%), geraniol (9.0\%), neral (5.3\%), } \beta \text {-bisabolene } \\
(8.4 \%) \text { and } \beta \text {-sesquiphellandrene }(10.6 \%)\end{array}$ & & \\
\hline- & Fresh & $\begin{array}{l}\text { Zingiberene + zingiberol (38.9\%), ar-curcumene }(17.7 \%) \text {, } \\
\beta \text {-sesquiphellandrene+ } \beta \text {-bisabolene (11\%), } \beta \text {-phellandrene } \\
(4.9 \%) \text {, linalool+a-terpiniol (3.8\%) }\end{array}$ & Bangalore Market & [16] \\
\hline $1.2 \%$ & Dried & $\begin{array}{l}\text { Zingiberene (32\%), } \beta \text {-sesquiphellandrene (15.6\%), } \beta \text {-bisabolene } \\
(9.3 \%) \text {, ar-curcumene }(15.9 \%)\end{array}$ & market Iran & [17] \\
\hline- & fresh & a-zingiberene (23.9\%), citral (21.7\%) & Brazil & [18] \\
\hline- & - & $\begin{array}{l}\text { Zingiberene (20-28\%), ar-Curcumene (6-10\%), } \\
\beta \text {-Sesquiphellandrene (7-11\%), } \beta \text {-Bisabolene (5-9\%) }\end{array}$ & Australia & [19] \\
\hline- & - & $\begin{array}{l}\text { a-zingiberene (29-40\%), } \beta \text {-Sesquiphellandrene (10-14\%), } \\
\text { ar-Curcumene (5-11\%), camphene (4.5-10\%), } \beta \text {-bisabolene } \\
(2.5-9 \%), \\
\text { a-zingiberene }(35-40 \%), \beta \text {-sesquiphellandrene } \\
(11.5-13.5 \%) \text {, ar-curcumene }(6.5-9 \%) \text {, camphene }(5-8 \%) \text {, } \\
\beta \text {-bisabolene }(2.5-5.5 \%) \\
\text { a-zingiberene }(23-45 \%), \beta \text {-sesquiphellandrene }(8-17 \%) \text {, } \\
\text { ar-curcumene }(3-11 \%), \text { camphene }(0.2-12 \%), \beta \text {-bisabolene }(3-7 \%)\end{array}$ & $\begin{array}{l}\text { China } \\
\text { India } \\
\text { west Africa }\end{array}$ & ISO 16928:2014 \\
\hline \multirow[t]{2}{*}{$2.22 \%-4.17 \%$} & unpeeled rhizomes cultivars & $\begin{array}{l}\text { Camphene }(8.49 \%) \text {, neral }(4.95 \%) \text {, geranial }(12.36 \%) \text {, zingiberene } \\
\text { (20.98\%) and } \beta \text {-sesquiphellandrene (7.96\%) }\end{array}$ & North-East India & [20] \\
\hline & - & $\begin{array}{l}\text { Zingiberene(10.5-16.6\%), ar-Curcumene (2.9-9.8\%), } \\
\beta \text {-Sesquiphellandrene (5.8-7.2\%), e-citral (7.4-10.5\%), z-citral } \\
\text { (5.3-7\%), o-cymene }(0.9-6.5 \%) \text {, camphene }(0.9-7.6 \%) \text {, } \\
\text { limonene }(1.3-6.4 \%)\end{array}$ & India & [21] \\
\hline $2.4 \% \mathrm{w} / \mathrm{w}$ & - & $\begin{array}{l}\text { Zingiberene }(29.5 \%) \text {, sesquiphellandrene }(18.4 \%) \text {, farnesene } \\
(6.46 \%) \text {, germacrene D }(3.58 \%) \text {, neral }(2.5 \%) \text {, geranial }(3.46 \%) \text {, }\end{array}$ & Nigeria & [11] \\
\hline $2.1 \%$ & - & $\begin{array}{l}\text { ar-cucumene (11.7-12.6\%), } \beta \text {-bisabolene (4.1-8.1\%) } \\
\text { a-zingiberene (10.3\%), } \beta \text {-sesquiphellandrene (7.4\%) }\end{array}$ & Vietnam & [22] \\
\hline- & - & $\begin{array}{l}\text { citral (30.8\%), zingiberene }(17.1 \%), \beta \text {-bisabolene, geranyl acetate }(6.7 \%) \text {, } \\
\beta \text {-Sesquiphellandrene }(5.9 \%), 1,8 \text {-cineol }(6.1 \%) \text { and geraniol }(6.1 \%)\end{array}$ & Alergia & [23] \\
\hline
\end{tabular}

(28.1\%), 1,8-cineole+limonene+ $\beta$-phellandrene (4.5\%), geraniol (9.0\%), neral (5.3\%), $\beta$-bisabolene (8.4\%) and $\beta$-sesquiphellandrene $(10.6 \%)$ as the main components [10]. The other ginger essential oil from Nigeria, extracted by hydro-distillation method $(2.4 \% \mathrm{w} / \mathrm{w})$ was containing zingiberene (29.5\%), sesquiphellandrene (18.4\%), farnesene (6.46\%), germacrene D (3.6\%), neral (2.5\%), geranial (3.56\%), neryl acetate (1.2\%), and $(E, E) \alpha$-farnesene $(1.9 \%)$ [11]. According to the results of above studies, the ginger dried rhizome had higher essential oil and $\beta$-zingiberene contents than that of fresh ones.

Furthermore, the drying method had been high effects on essential oil's yield and the chemical composition of ginger rhizomes. It has been confirmed that drying the rhizomes in temperature lower than $70{ }^{\circ} \mathrm{C}$ increased the yield of ginger oil, without any effect on transformation of 6-gingerol to 6-shogaol, while temperature higher than $70{ }^{\circ} \mathrm{C}$ promoted transformation of 6-gingerol to 6-shogaol [12]. The essential oil from mature freeze-dried ginger rhizome (Hsinchu, Taiwan), which extracted by hydrodistillation method and low temperature extraction using liquid $\mathrm{CO}_{2}$ method, resulted in degradation of non-volatile gingerol contents [13]. Furthermore, zingiberene $(27.8 \%), \beta$-phellandrene $(12.9 \%)$, sesquiphellandrene $(10.4 \%)$, geranial $(6.6 \%), \alpha$-curcumene $(5.8 \%)$, and $\beta$-bisabolene $(5.7 \%)$ were as the main components of fresh ginger oil, while drying at $80{ }^{\circ} \mathrm{C}$ for $1 \mathrm{~h}$ was resulted in zingiberene (26.4\%), sesquiphellandrene (10.2\%), $\beta$-phellandrene (10.0\%), camphene $(7.6 \%)$, geranial $(6.6 \%)$, ar-curcumene $(6.0 \%)$, and $\beta$-bisabolene $(5.4 \%)$ as its main components. Drying these rhizomes by microwave at $700 \mathrm{~W}$ for 2 min resulted in zingiberene $(37.1 \%), \beta$-sesquiphellandrene (12.8\%), $\beta$-bisabolene (12.8\%), ar-curcumene (8.5\%), and $\beta$-phellandrene (7.4\%) as the main compounds. Essential oil of silica gel dried rhizome had been zingiberene (30.2\%), sesquiphellandrene (12.2\%), geranial (8.1\%), $\beta$-phellandrene (7.7\%), ar-curcumene (6.3\%), and $\beta$-bisabolene $(6.2 \%)$ [12]. Drying the fresh ginger by convection drying, and microwave drying methods at PL 100 resulted in 2.9 and $3 \% \mathrm{v} / \mathrm{w}$ yield oil versus $3.2 \%$ for ginger oil from fresh rhizome. Zingiberene (23.5\%), $\alpha$-farnesene (12.0\%), $\beta$-sesquiphellandrene (10.3\%) and ar-curcumene (5.5\%) were the main components of fresh ginger oil. The concentration 
of zingiberene decreased in essential oils from rhizome dried by convection drying or microwave PLS higher than 100. The extracted essential oil from dried ginger rhizome by microwave PL100 had higher gingerol content (about 7\%) due to reduction in drying time [14]. Therefore, the drying method, freshness or dryness and time exposure of rhizome to heat [14] can influence on chemical composition and yield of essential oils. The number of phytochemical compounds in ginger oil from dried rhizomes had higher than the oils from fresh ones (115 vs. 63) [15].

Zingiberene + zingiberol (38.9\%), ar-curcumene (17.7\%), $\beta$-sesquiphellandrene $+\beta$-bisabolene $(11 \%), \beta$-phellandrene (4.9\%) were the main components of simultaneous distillation extracted ginger oil from fresh rhizome (Bangalore market) [16]. Zingiberene (32\%), $\beta$-sesquiphellandrene (15.6\%), $\beta$-bisabolene (9.3\%), and ar-curcumene (15.9\%) were the main components of ginger oil (Iran market) from dried rhizome, which is extracted by hydro-distillation method (1.2\% w/w) [17]. $\alpha$-zingiberene (23.9\%) and citral $(21.7 \%)$ were the main components of essential oil from fresh ginger rhizome, which is extracted by hydro-distillation method [18]. Zingiberene (20-28\%), ar-curcumene (6-10\%), $\beta$-sesquiphellandrene (7-11\%), and $\beta$-bisabolene $(5-9 \%)$ were the main components of Australian ginger essential oil [19].

According to ISO 16928:2014, the pale yellow to amber ginger oil from China should be containing $\alpha$-zingiberene (29-40\%), $\beta$-sesquiphellandrene (10-14\%), ar-curcumene (5-11\%), camphene $(4.5-10 \%)$, and $\beta$-bisabolene $(2.5-9 \%)$, while yellow ginger oil from India should be containing $\alpha$-zingiberene (35-40\%), $\beta$-sesquiphellandrene (11.5-13.5\%), ar-curcumene (6.5-9\%), camphene (5-8\%), and $\beta$-bisabolene (2.5-5.5\%). The pale yellow essential oil from West Africa had $\alpha$-zingiberene (23-45\%), $\beta$-sesquiphellandrene (8-17\%), ar-curcumene (3-11\%), camphene (0.2-12\%), and $\beta$-bisabolene (3-7\%). The essential oil from unpeeled rhizomes cultivars from North-East India $(2.22-4.17 \% \quad w / w)$ had camphene (8.49\%), neral (4.95\%), geranial (12.36\%), zingiberene $(20.98 \%)$ and $\beta$-sesquiphellandrene (7.96\%) [20]. The chemical compositions of ginger oils are affected from geographical condition. Ginger oils, extracted by hydro-distillation method from three different geographical locations of India (Mizoram, Chennai and two varieties from Sikkim) had zingiberene (10.5-16.6\%), ar-curcumene (2.9-9.8\%), $\beta$-sesquiphellandrene (5.8-7.2\%), e-citral (7.4-10.5\%), z-citral (5.3-7\%), o-cymene (0.9-6.5\%), camphene (0.9-7.6\%), and limonene (1.3-6.4\%) [21]. Ginger rhizome essential oil from Vietnam was extracted by water or steam distillation method (yields $2.1 \%$ and $2.05 \%$, respectively). ar-curcumene (11.7\%) and $\beta$-bisabolene (4.1\%) were the main components of essential oil, extracted by steam distillation, while ar-curcumene (12.6\%), $\alpha$-zingiberene (10.3\%), $\beta$-bisabolene $(8.1 \%)$ and $\beta$-sesquiphellandrene $(7.4 \%)$ were present in essential oil extracted by steam distillation [22]. The ginger essential oil from Algeria had citral (30.8\%), zingiberene (17.07\%), $\beta$-bisabolene, geranyl acetate $(6.7 \%), \beta$-sesquiphellandrene (5.9\%), 1,8-cineol (6.1\%) and geraniol (6.1\%) [23].

The other effective factor on chemical composition of oil is the method, which is used for extraction of ginger oil. The essential oil from Brazilian ginger rhizomes, which were extracted by hydro-distillation method and supercritical fluid extraction using $\mathrm{CO}_{2}$ had lower extraction's yield in hydro-distillation method than that of supercritical fluid extraction method. $\alpha$-zingiberene, $\beta$-sesquiphellandrene, ar-curcumene, $\alpha$-farnesene, $\beta$-bisabolene and geranial were the main components of ginger oil extracted by supercritical critical extraction using $\mathrm{CO}_{2}$ (at $25 \mathrm{MPa}$, temperature $333.15 \mathrm{~K})$. ar-curcumene, geranial and camphene were the main components of hydro-distilled ginger essential oil. The content of $\alpha$-zingiberene was lower in hydro-distilled ginger essential oil [24]. Furthermore, the highest yield for essential oil (3.1\%) and 6-gingerol content (20.7\%) were achieved by supercritical fluid extraction at $15 \mathrm{MPa}, 35{ }^{\circ} \mathrm{C}$ and $15 \mathrm{~g} / \mathrm{min}$. The essential oil yield for scale up of this method was $3.83 \%$ with $18 \%$ of 6 -gingerol. The essential oil's yield was $1.9 \%$ with 6 -gingerol content of $14.8 \%$ for high pressure Soxhlet with $\mathrm{CO}_{2}$. Extraction of essential oils with other methods such as Soxhlet with n-hexane or ethanol percolation had disadvantages of residual solvent and low content of 6-gingerol (4.59-6.26\%) [25]. Proteolytic enzyme (Zingibain), oleoresin, vitamins, minerals, gingerols, shogaols, paradols and zingerone were found in ginger essential oil [26] and has been confirmed that $\gamma$-irradiation of rhizome (60 Gy) had no detectable effects on qualitative and quantitative of components of extracted essential oil [16]. The citral content of ginger essential oil from dried rhizome was lower than the oil from fresh ginger. The unpeeled or coated rhizomes had the better yield of essential oil [27]. The structure of main components in ginger essential oil is presented in Fig. 1. Therefore, defining a protocol for gathering, drying and extraction method help to prepare a standard on chemical profile of ginger essential oil by international organizations in order to overcome the diversity of chemical composition of essential oil.

\section{Pharmacological effects of ginger essential oil}

Although, the chemical compositions of ginger essential oil are affected from many factors, but different pharmacological and biological activities are reported for ginger essential oil in different literatures.

\section{Antimicrobial activity of ginger essential oil}

Brazilian ginger rhizomes essential oil with main components of $\alpha$-zingiberene, $\beta$-sesquiphellandrene, ar-curcumene, $\alpha$-farnesene, $\beta$-bisabolene and geranial had the higher inhibition zone diameters for Staphylococcus aureus and Listeria monocytogenes, followed by 
<smiles>C=C1C=CC([C@@H](C)CCC=C(C)C)CC1</smiles>

B-zingiberene

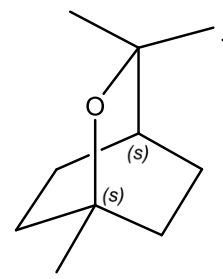

1,8-cineole<smiles>C=C(C)C1CC=C(C)CC1</smiles>

limonene<smiles>C=C1C=CC(C(C)C)CC1</smiles>

B-Phellandrene<smiles>CC(C)=CCCC(C)=CCO</smiles><smiles>CC(C)=CCCC(C)=CC=O</smiles><smiles>C=C(CCC=C(C)C)[C]1CC=C(C)CC1</smiles>

neral

b-Bisabolene<smiles>C=C1C=CC(C(C)CCC=C(C)C)CC1</smiles><smiles>CC(=O)OCC=C(C)CCC=C(C)C</smiles><smiles>CCCCCC(CCC=C(C)C)c1ccc(C)cc1</smiles>

geranyl acetate

alpha-curacumene

Fig. 1 Main components of ginger oil

Pseudomonas aeruginosa. Salmonella typhimurium, Shigella flexneri and Escherichia coli were resistant to ginger essential oil [24]. The higher sensitivity of $S$. aureus than that of $E$. coli to ginger essential oil were confirmed in other study [28]. Ginger essential oil exhibited the MIC values of $8.69,86.92,173.84$ and $869.2 \mathrm{mg} / \mathrm{ml}$ for $S$. aureus, Bacillus subtilis, E. coli and Penicillium spp. [29]. The antibacterial evaluation of ginger essential oil against Gram negative bacteria; Escherichia coli ATCC 25922, Acinetobacter baumannii ATCC 19606, Pseudomonas aeruginosa ATCC 27853, and 30 multidrug-resistant (MDR) A. baumannii isolates showed the inhibition zone diameters of $11.5,6,6,10 \mathrm{~mm}$. The $\mathrm{MIC}_{50}$ and $\mathrm{MIC}_{90}$ values of ginger essential oil were 2 and $4 \mathrm{mg} / \mathrm{ml}$ against MDR- $A$. baumannii. The corresponding MBC were $4 \mathrm{mg} / \mathrm{ml}$. Tea tree oil was used as positive control in this study with $\mathrm{MIC}$ and $\mathrm{MBC}$ values of 2 and $4 \mathrm{mg} / \mathrm{ml}$, respectively [30]. The antifungal activity of Vietnamese ginger essential oil with ar-cucumene, $\beta$-bisabolene, $\alpha$-zingiberene and $\beta$-sesquiphellandrene against Botrytis cinerea, Penicillium sp., Aspergillus niger, followed by Rhizopus nigricans, Saccharomyces cerevisiae, and Candida albicans, were confirmed. Bacillus subtilis, Staphylococcus epidermidis, Salmonella abony, Escherichia coli, and Bacillus pumilus showed less sensitivity to Vietnamese ginger essential oil. Pseudomonas aeruginosa was resistant to ginger essential oil [22]. Ginger essential oil had less activity against Streptococcus pneumoniae R36A [31]. The ginger essential oil had antibacterial effects against Campylobacter jejuni, E. coli $\mathrm{O}_{157}: \mathrm{H}_{7}$, L. monocytogenes, and 
Salmonella enterica [32]. The ginger essential oil with citral (30.8\%) and zingiberene (17.07 \%), $\beta$-bisabolene, geranyl acetate $(6.7 \%), \quad \beta$-sesquiphellandrene $(5.9 \%)$, 1,8-cineol (6.1\%) and geraniol (6.1\%) showed antimicrobial activity against $S$. aureus ATCC 25923, Streptococcus pyogenes ATCC 19615, B. subtilis ATCC 6633, Salmonella typhi ATCC 23564, A. niger ATCC 9029, and P. aeruginosa ATCC 27853. E. coli ATCC 25922, Citrobacter koseri ATCC 27028 and Proteus mirabilis ATCC 29906 exhibited less sensitivity to ginger essential oil [23]. It seems that ginger essential oil showed the best antibacterial activity against Gram positive bacteria than that of Gram negative ones. Also, the results of antibacterial effects of ginger essential oil showed that this activities influence from the chemical composition of ginger essential oil. Furthermore, the antifungal activities of ginger essential oils had been the subjects of other research studies.

Ginger essential oil showed anti-dermatophyte effects against Trichophyton rubrum, and Microsporum gypseum. Also, a synergistic effects between Curcuma longa and ginger essential oils were confirmed against $T$. rubrum, and $M$. gypseum [33]. Ginger essential oil with zingiberene (37.65\%), $\delta$-amorphene (19.8\%), $\alpha$-curcumin (11.3\%), and $\alpha$-bisabolene (10.4\%) had significant effects on $A$. flavus growth and aflatoxin $\mathrm{B}_{1}$ and $\mathrm{B}_{2}$ production [34]. The fresh ginger rhizome essential oil containing $\alpha$-zingiberene (23.9\%) and citral (21.7\%) inhibited Fusarium verticillioides with MIC value of $2.5 \mathrm{mg} / \mathrm{ml}$. An oscillation in ergosterol production was caused after exposure to $0.5-3 \mathrm{mg} / \mathrm{ml}$ ginger essential oil and ergosterol production was inhibited in higher concentrations of ginger essential oil (57-100\%). Ginger essential oil inhibited the production of fumonisin $B_{1}$, and $B_{2}$. Correlation between the inhibition of ergosterol biosynthesis and fumonisin production is associated with reduction in fungal biomass. Ginger essential oil decreased cytoplasmic content of fungi and interrupted membrane integrity [18]. The results of antimicrobial evaluations of ginger essential oil propose it as broad spectrum antimicrobial agents (Table 2) in pharmaceutical industry or as natural preservative in food or cosmetic industries.

\section{Antioxidant activity of ginger essential oil}

Production of free radicals in the body and its relation with different human diseases, investigation on natural antioxidants has increased among the scientists.

The antioxidant evaluation of Chinese ginger essential oil had $\mathrm{EC}_{50}(\mathrm{mg} / \mathrm{ml})$ of $63.23,11.68$ and 0.118 in reducing power, DPPH scavenging and $\mathrm{H}_{2} \mathrm{O}_{2}$ scavenging assays. The corresponding $\mathrm{EC}_{50}$ for ascorbic acid were $0, .025,0.005,0.478$, respectively and for quercetin were $0.017,0.002,0.078$ [35]. Ginger essential oil also showed antioxidant activity in ABST assay. 0.87 to $869.2 \mathrm{mg} / \mathrm{mL}$ essential oil showed $12.1-80.53 \%$ radical scavenging activity versus $7.5-69.3 \%$ for $0.08-0.6 \mathrm{mg} / \mathrm{ml}$ ascorbic acid. $\mathrm{IC}_{50}$ of ABST $(\mathrm{mg} / \mathrm{ml})$ were $1.82 \pm 0.034$ for ginger essential oil [29]. Intra-peritoneal injection of ginger essential oil scavenged the superoxide, hydroxide radicals and inhibited tissue lipid peroxidation. $250 \mathrm{mg} / \mathrm{kg}$ ginger essential oil suppressed (18.25\%) phorbol 12-myristate 13-acetate (PMA) induced superoxide radicals in macrophages. Oral administration of 100 or $200 \mathrm{mg} / \mathrm{kg}$ ginger essential oil for 30 days in mice increased the antioxidant enzymes such as catalase, super oxide dismutase, glutathione, glutathione reductase in blood compared with control group (paraffin oil). Ginger essential oil increased the level of superoxide dismutase, glutathione peroxidase and glutathione-s-transferase in liver [27]. The results of studies showed the role of ginger essential oil in protecting the cells from extracellular deleterious radicals, by increasing the serum and liver antioxidant enzymes.

\section{Bronchodilator effects of ginger oil}

The bronchodilator effects of ginger essential oil were confirmed on airway system. Ginger essential oil with citral, eucalyptol and camphor had relaxing effect on rat's airway and inhibited the carbachol induced rat tracheal contraction. The bronchodilator effect of ginger essential oil is related to citral, eucalyptol. The bronchodilator effects of ginger essential oil reversed by propranolol, while L-NAME and indomethacin had no effect on bronchodilator effects of ginger essential oil and citral. Propranolol is $\beta$-adrenergic receptor antagonist, while indomethacin and L- NAME were $\mathrm{CO}_{2}$ inhibitor and NOS inhibitor. Therefore, $\beta$-adrenergic receptors were involved in bronchodilator effects of ginger essential oil [36]. The bronchodilator effects of ginger essential oil are according to traditional uses of ginger syrup for respiratory problems. The bronchodilator effects of ginger essential oil in modern medicine confirm its traditional uses for management of cough.

\section{Anti-inflammatory and analgesic effects of ginger essential oil}

Inflammation plays important role in the body. The anti-inflammatory effects of ginger essential oil were evaluated in streptococcal cell wall-induced rheumatoid arthritis model in female Lewis arthritis. Daily Intraperitoneal injection of $28 \mathrm{mg} / \mathrm{kg}$ ginger essential oil inhibited the chronic joint inflammation without any effects in initial acute phase of joint inflammation or granuloma formation at the site of streptococcal cell wall deposition in liver. Ginger essential oil acts as phytoestrogen without any in vivo effect on estrogen target organ [37]. The anti-edema effects of ginger essential oil $(100,500$ and $1000 \mathrm{mg} / \mathrm{kg})$ in carrageenan induced paw 


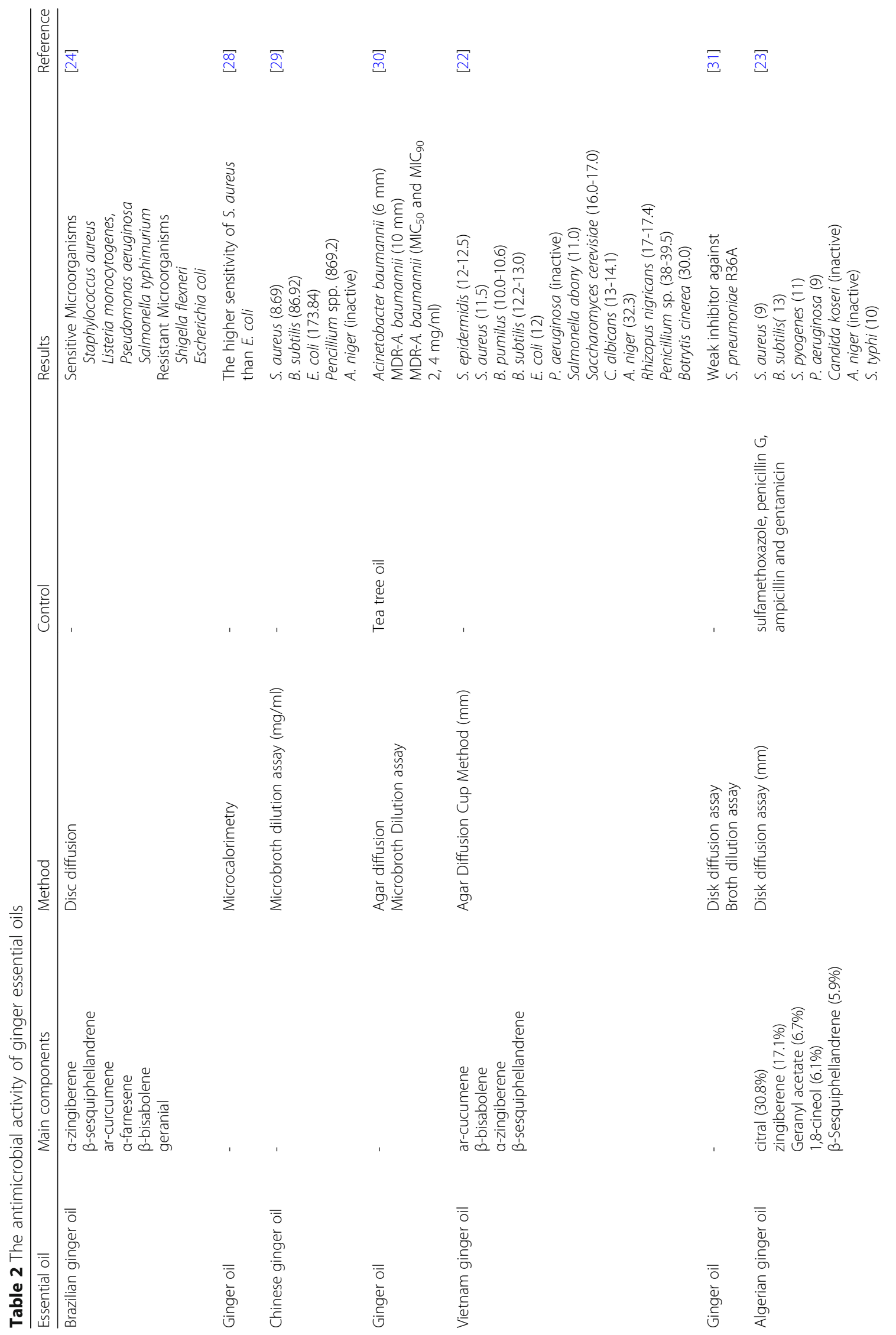




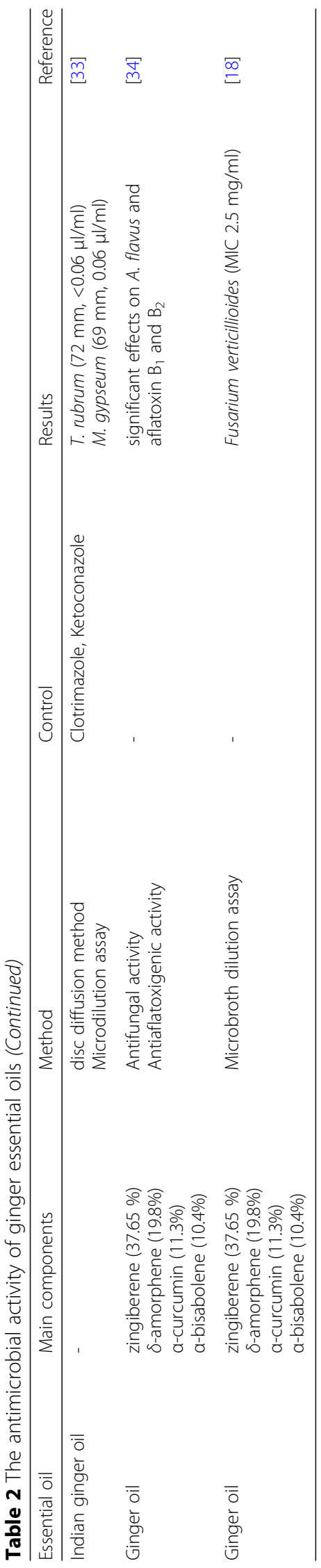


edema of mice were $27.8,44.4$ and $61.1 \%$ in a dose dependent manner vs. $55.6 \%$ for $10 \mathrm{mg} / \mathrm{kg}$ diclofenac. Ginger essential oil showed inhibitory effects against dextran induced inflammation. Ginger essential oil suppressed the chronic inflammation induced by formalin. 100,500 and $1000 \mathrm{mg} / \mathrm{kg}$ ginger essential oil showed inhibitory effects on formalin induced inflammation about $54.17,62.5$ and $70.8 \%$, respectively vs. $54.8 \%$ for $10 \mathrm{mg} /$ $\mathrm{kg}$ diclofenac. In carrageenan induced inflammation, the anti-inflammatory mediators such as histamine, bradykinins and prostaglandins were involved. Due to the anti-inflammatory effects of ginger essential oil in kinin, carrageenan induced paw edema and chronic edema, it seems that the anti-inflammatory effects of ginger essential oil is related to inhibition of prostaglandin release [27]. The analgesic effects of ginger essential oil in acetic acid writhing model showed that 100, 500 and $1000 \mathrm{mg} /$ $\mathrm{kg}$ ginger essential oil inhibited the writhing reflux by $13.1 \%, 70.64 \%$ and $92.15 \%$. The analgesic effects of 500 $\mathrm{mg} / \mathrm{kg}$ ginger essential oil was comparable with $10 \mathrm{mg} / \mathrm{kg}$ aspirin. The antinociceptive effects of ginger essential oil is strong and is related to inhibition of arachidonic acid metabolite synthesis by cyclooxygenase inhibition [27].

Evaluating the anti-inflammatory/analgesic effects of ginger essential oil (2\%) in Male Sprague rats by Randall Selitto assay exhibited that ginger essential oil significantly increased the threshold of hind paw for $1 \mathrm{~h}$. Counting the c-Fos positive spinal neuron in rat's spinal cords showed ginger essential oil completely suppressed the pressure induced in the dorsal horn of spinal cord, which implicating that the inhibitory effects of ginger essential oil on pain transmission in primary sensory neurons of the dorsal root ganglia or at the spinal cord level. The suppressor effects of ginger essential oil on Complete Freund's Adjuvants-induced-paw edema implicated on its anti-inflammatory effects [38]. The analgesic effects of ginger essential oil were investigated again in mice using hot plate and acetic acid test. $0.25-1$ $\mathrm{g} / \mathrm{kg}$ ginger essential oil had significant analgesic effects in hot plate and acetic acid test. $1 \mathrm{~g} / \mathrm{kg}$ ginger essential oil reduced the writhes about $64.3 \%$ compared to $81.3 \%$ for indomethacin $(0.01 \mathrm{~g} / \mathrm{kg}) .1 \mathrm{~g} / \mathrm{kg}$ ginger essential oil caused prolong ratio of $243.1 \%$ in hot plate test compared to $274.5 \%$ for indomethacin. $0.25-1 \mathrm{mg} / \mathrm{kg}$ ginger essential oil reduced inflammation in carrageenan induced rat paw edema, adjuvant arthritis and inhibited inflammatory mediators, which induced vascular permeability. Ginger essential oil at concentration of $1 \mathrm{~g} / \mathrm{kg}$ reduced the hind paw edema about $66.5 \%$ in carrageenan test, while the corresponding value was $80.5 \%$ for $0.5 \mathrm{~g} /$ $\mathrm{kg}$ aspirin. $1 \mathrm{~g} / \mathrm{kg}$ ginger essential oil reduced $35.6 \%$ edema in Freund's adjuvant-induced arthritis in rats vs. $51.9 \%$ for $0.0025 \mathrm{~g} / \mathrm{kg}$ dexamethasone. $0.5 \mathrm{~g} / \mathrm{kg}$ ginger essential oil inhibited the inflammatory mediators of bradykinins, histamine and arachidonic acid, comparable to $0.01 \mathrm{~g} / \mathrm{kg}$ indomethacin [39].

The effect of ginger essential oil on leukocyte chemotaxis in vitro condition showed that treatment with ginger essential oil decreased the leukocyte migration toward casein stimuli. Pretreatment with dexamethasone suppressed casein induced leukocyte migration. After oral pretreatment of carrageenan injected mice with 200 or $500 \mathrm{mg} / \mathrm{kg}$ ginger essential oil, a reduction in number of rolling, adherent cells and migrated leukocytes were observed and this effects were comparable with $5 \mathrm{mg} / \mathrm{kg}$ indomethacin [40].

The results of preclinical studies on analgesic and anti-inflammatory effects of ginger essential oil were evaluated in clinical studies.

In randomized controlled trial, the effects of Swedish massage with ginger essential oil ( $2 \%$ in jojoba oil) were compared to Thai massage on 140 older adult patients with chronic low back pain and disability. The patients were randomly divided in two groups and treated with Swedish massage with ginger essential oil or Thai massage $30 \mathrm{~min}$, twice a week for five weeks. The effectiveness of treatment was evaluated by Visual Analogue Scale (VAS) after each massage, McGill Pain Questionnaire after 6 (short term) and 15 weeks (long term) and Owestry Disability Questionnaire (ODQ). At the baseline, there was no significant difference between two groups, in regard of demographic and back pain characteristic. A significant reduction in pain intensity was observed in both groups immediately after massage compared to baseline, but this difference between two groups was not significant immediately after the massages. Evaluation the McGill Pain scores exhibited a greater reduction in back pain intensity in Swedish massage with ginger essential oil than the Thai massage. Two types of massages reduced back pain intensity. Evaluation the effects of treatment on disability showed a significant difference between two groups after treatment. More reduction in ODQ was observed in Swedish massage with ginger essential oil than that of Thai massage. The disability rating improved across the period of treatment in both groups, but this improvement was higher in Swedish massage with ginger essential oil group. The results of this clinical study showed the immediate, short and long effectiveness of treatments with ginger essential oil [41]. In other double blind placebo controlled experimental study, the effectiveness of massage with $1 \%$ ginger essential oil plus $0.5 \%$ orange essential oil in olive oil was evaluated on fifty nine older patients with moderate to severe knee pain. The patients massaged twice a weeks for 3 -weeks period. The patients were evaluated at the baseline, post 1-week and post 4-weeks after therapy by evaluation of knee pain intensity, stiffness level and physical functioning and quality 
of life. 19, 17 and 17 patients completed the study in intervention, placebo and control groups, respectively. The patients in intervention group received an aromatic oil massage with essential oils, the placebo group received olive oil massage, and control group received no massage, but had conventional treatments. There was no significant difference between groups in regard of socio-demographic characteristic and outcome measures, the use of oral analgesic and NSAIDs. Greater pain and poorer in fulfilling physical roles was observed in patients of control group than that of placebo and intervention groups. Reduction in knee pain and stiffness relief were similar among three groups at post 1 and 4-week of treatments, but within groups, the reduction in knee pain rating and stiffness relief outcomes were significant in intervention group $(\mathrm{p}=0.02, \mathrm{p}=0.03)$, while in placebo group and control group, no significant reduction was observed. Within group, physical functions showed more improvement in intervention group than the placebo or control group. No significant difference was observed in life quality between baselines and post 4-week for all groups. No major adverse effects were reported during the study for all groups, only one patient in placebo group reported more pain after massage therapy [42]. Massage therapy with ginger essential oil relieved moderate to severe knee joint pain, daily function and stiffness in short term without adverse effects and effects on quality of life. The anti-inflammatory and analgesic effects of ginger essential oil confirm the traditional uses of ginger root in treatment of inflammatory diseases of gastrointestinal tracts. Therefore, it could be a good natural treatment for Irritable Bowel syndrome (IBS), colic or musculoskeletal pain.

\section{Anticancer effects of ginger essential oil}

Anticancer effects of ginger essential oil were the other subject of investigation. The $\mathrm{IC}_{50}$ values for $46.2-172 \mu \mathrm{g} /$ $\mathrm{ml} \alpha$-zingiberene as one main component of ginger essential oil was reported 60.6, 46.2, 172 and $80.3 \mu \mathrm{g} / \mathrm{ml}$ for HeLa, SiHa, MCF-7 and HL-60 cell lines. $\alpha$-zingiberene caused nucleosomal DNA fragmentation, increased the percentage of sub-diploid cells, apoptosis, activated the caspases in $\mathrm{SiHa}$ cells. The $\mathrm{IC}_{50}$ values of ginger essential oil with $\alpha$-zingiberene (35.0\%), ar-curcumene (15.3\%), $\beta$-sesquiphellandrene (12.3\%) were in the ranges of 38.6-82 $\mu \mathrm{g} / \mathrm{ml}$ against cell lines. The lowest $\mathrm{IC}_{50}$ for ginger oil was related to $\mathrm{SiHa}(38.6 \mu \mathrm{g} / \mathrm{ml})$. The $\mathrm{IC}_{50}$ values of cisplatin as control group were 28.2, 56.2, 31.2 and 31.1 for HeLa, SiHa, MCF-7 and HL60, respectively [43].

The neutral red (NR) and tetrazolium MTT assays confirmed the cytotoxic effects of ginger essential oil (camphene, 1,8-cineole, $\beta$-phellandrene, neral, and geranial) against HepG2 and HeLa cells. The MTT-IC $\mathrm{I}_{50}(\mu \mathrm{l} / \mathrm{ml})$ values of ginger essential oil were 635.1 and 141.4 for
HepG2 and HeLa cells, respectively. The corresponding NRU-IC 50 was 635.1 and $129.9 \mu \mathrm{l} / \mathrm{ml}$, respectively. The anti-proliferative effects of ginger essential oil against HeLa cervical cancer cells are created by cell membrane protrusions, blebbing and chromatin condensation. Increasing the concentration of ginger essential oil to 1928 $\mu \mathrm{l} / \mathrm{ml}$ caused the amorphous cells, blebbing and chromatin condensation, which finally caused cell death by apoptosis, similar to those of camptothecin [44]. In other preclinical study, $10 \mu \mathrm{l} /$ day ginger essential oil for 14 days on acid soluble sulfhydryl levels and hepatic carcinogen metabolizing enzymes (cytochrome P450, aryl hydrocarbon hydroxylase and glutathione-S-transferase) in Swiss albino mice showed that ginger essential oil significantly increased aryl hydrocarbon hydroxylase and glutathione-S-transferase [45].

\section{Anti-ulcer effects of ginger essential oil}

Ginger essential oil can be used as anti-ulcer agent for treatment of gastrointestinal ulcers. The gastric protective effects of $0.5,1 \mathrm{~g} / \mathrm{kg}$ ginger essential oil (5 days) in aspirin-pylorus ligation induced ulcer model in Wistar rats by evaluating the ulcer index, serum $\gamma$-GTP levels, gastric wall mucus thickness and total acidity of gastric juice showed no significant changes on volume of gastric juice, but a reduction in serum $\gamma$-GTP levels and increase in the means of gastric wall mucus thickness were observed. Oral omeprazole treatment $(10 \mathrm{mg} / \mathrm{kg})$ significantly reduced the serum $\gamma$-GTP levels, ulcer index, and total acidity with increase in gastric wall mucus thickness. Omeprazole had no effects on volume of gastric juice compared to control group. In control group, a significant increase in serum $\gamma$-GTP levels, ulcer index and reduction in gastric wall mucus thickness was observed [46]. Furthermore, oral ginger essential oil (zingiberene (28.1\%), ar-curcumene (14.1\%), $\beta$-bisabolene (13.2\%), $\alpha$-sesquiphellandrene (12.9\%), sabinene (9.3\%) and camphene $(4.1 \%)$ had protective effects against ulcerative colitis induced by acetic acid. The colon weight/length ratio reduced after treatment with different concentrations of ginger essential oil (100, 200 and $400 \mathrm{mg} / \mathrm{kg}$ ) for 5 days. Ulcer severity, ulcer area and ulcer index reduced after administration of 200 and $400 \mathrm{mg} / \mathrm{kg}$ ginger essential oil. $400 \mathrm{mg} / \mathrm{kg}$ ginger essential oil reduced the inflammation extent and severity. In this animal study, the ulcer score, ulcer area, ulcer index for $400 \mathrm{mg} / \mathrm{kg}$ ginger essential oil was comparable to $4 \mathrm{mg} / \mathrm{kg}$ prednisolone [47]. Ginger essential oil had good potency for treatment of ulcerative colitis or gastric ulcers in animal studies, therefore, its potency can be evaluated in large human clinical studies.

Immuno-modulatory effects of ginger essential oil Ginger essential oil is known as immunomodulator agent. The effect of ginger essential oil on cellular immune 
response was the subject of different investigations. $0.001-10 \mathrm{ng} / \mathrm{ml}$ ginger essential oil had significant inhibitory effects on $\mathrm{T}$ lymphocyte proliferation. Also, the number of total $\mathrm{T}$ lymphocytes and $\mathrm{T}$ helper cells decreased in a dose dependent. The percentage of T suppressor cells to the total $\mathrm{T}$ lymphocyte increased in mice after treatment with ginger essential oil. IL- $1 \alpha$ secretion by mice peritoneal macrophages, which implicated on its anti-inflammatory effects, was inhibited by ginger essential oil. In animal model, reduction in delayed type of hypersensitivity response to 2, 4-dinitro1-fluorobenzene was observed in sensitized mice after oral administration of $0.125,0.25$ and $0.5 \mathrm{~g} / \mathrm{kg}$ ginger essential oil. Oral administration of ginger essential oil had significant effects on reduction of thymus and spleen index [48]. The results of this study confirmed the effects of ginger essential oil on cell mediated immune response and nonspecific proliferation of $\mathrm{T}$ lymphocyte.

\section{Other pharmacological effects of ginger essential oil}

The use of ginger essential oil in reducing of high risk of post-operative nausea and vomiting was the subject of clinical study. A solution of ginger essential oil (5\% in grape seed oil) was applied naso-cutaneously in management of nausea in general anesthesia of patients with high risk of post-operative nausea and vomiting. Ginger oil solution was applied on both wrists and inserted to anesthesia medication. The results of study showed the lower incidence of nausea and vomiting in ginger essential oil treated patients in post anesthesia recovery unit about $20 \%$. In ginger essential oil group, the high risk patients with post-operative nausea and vomiting received only one single intravenous supplemental medication to control nausea. The patients in control group experienced post-operative nausea and vomiting about $50 / 50$. Ginger essential oil was tolerated by patients and is regarded as safe treatment [49]. Ginger rhizomes as an effective and safe treatment and adjuvant treatment for nausea and vomiting in pregnancy and chemotherapy-induced nausea were confirmed in various preclinical and clinical studies [50].

The anti-emetic effect of ginger essential oil is related to shogaols and 6-, 8-, and 10-gingerols [51]. The warming effect of ginger essential oil is mediated by decreasing the body serotonin [52]. 6-shogaol inhibits the release of substance P and shows capsaicin like effect [53]. The anxiolytic effect of ginger essential oil was confirmed [54].

The pesticide effect of ginger essential oil was confirmed against adults and larva of Dermestes maculatus De Geer (adult and larva). $1.33 \mu \mathrm{l} / \mathrm{ml}$ essential oil exposure of adult pesticide for $6 \mathrm{~h}$ caused $36.2 \%$ mortality. The larva was more sensitive than that of adults. The percentage of mortality increased with time exposure of pest with essential oil. The $\mathrm{LD}_{90}$ of ginger essential oil were 12.92, 5.14 and 3.06 after 6,12 and $18 \mathrm{~h}$ exposure of $D$. maculatus larva. The corresponding $\mathrm{LD}_{90}$ were $6.52,4.64$ and 4.64 on adults of D. maculatus [55].

\section{Safety}

Ginger has liver metabolism, therefore it rapidly eliminates from the blood after oral ingestion. According to monographs on fragrance raw materials (Research institute on Fragrance materials, 1972), the usual acceptance concentrations of ginger essential oil in soap, detergent, creams-lotion and perfumes are 0.01, 0.001, 0.005 and 0.08 , respectively, while higher than $0.1,0.01,0.03$ and $0.4 \%$ are not permitted in food. Ginger essential oil is approved by FEMA and FDA as GRAS for food uses. The $\mathrm{LD}_{50}$ of ginger essential oil was reported $3.197 \mathrm{~g} / \mathrm{kg}$ in mice [39].

The acute oral $\mathrm{LD}_{50}$ in rats and the acute dermal $\mathrm{LD}_{50}$ in rabbits were higher than $5 \mathrm{~g} / \mathrm{kg}$. The applied pure ginger essential oil on the backs of hairless mice had no irritating reaction. Pure essential oil on intact or abraded rabbit skin for $24 \mathrm{~h}$ under occlusion caused moderate irritating. $4 \%$ ginger essential oil in petrolatum caused no irritation and no sensitization after $48 \mathrm{~h}$ closed patch test in human subjects, but the dermal products containing ginger essential oil may produce dermatitis in hypersensitive individuals [56].

Oral administration of ginger essential oil $(0.3,0.6$ and $1.2 \mathrm{~g} / \mathrm{kg}$ ) for 180 days in dogs reduced the thymus and spleen index, furthermore, $0.5,1.0$ and $2.0 \mathrm{~g} / \mathrm{kg}$ ginger essential oil to rats for 180 days had no effects in thymus and spleen index. Histopathological examinations of thymus and spleen samples showed reduction in the number of $\mathrm{T}$ lymphocytes in thymus and mild degeneration in adrenal gland cortex in both animals. Discontinuing the treatment for 30 days recovered the animals to the normal level [57]. Oral daily administration of rats with 100, 250 and $500 \mathrm{mg} / \mathrm{kg}$ for 13 weeks caused on changes in hematological parameters, serum electrolyte, renal functions or histopathology of vital organs [58]. Ginger one dose dependently inhibited the spontaneous contractile movements in the isolated colonic segments and colonic motility in rats without any effect on blood pressure and heart rate via direct effect on smooth muscle [59].

3-4 cups of Tea ( 1 tablespoon grated raw root per cup with boiling water), 1-2 g powder, and $1.5-3 \mathrm{ml}$ of tincture (three times), are recommended daily. The pregnant women do not use the ginger higher than $1 \mathrm{~g}$, and should not exceed $4 \mathrm{~g}$ per day in general population. Due to the effect of ginger to increase the risk of bleeding, the use of ginger should discontinue 1-2 weeks before surgical procedures [60]. 


\section{Conclusion}

Although, Ginger rhizome is known as spice in different cultures, and the majority of studies have been focused on anti-emetic, anti-vomiting and analgesic effects of ginger extracts, attention to ginger essential oil in management of gastrointestinal tract's diseases with ulcer and pain, respiratory system with infection should be considered. Ginger essential oil is extracted from ginger rhizomes, which the chemical composition of ginger oils influences from geographical region, extraction methods, freshness or dryness of rhizomes. Due to the chemical composition of ginger oil is affected from many different factors such as geographical condition, freshness or dryness of rhizome, methods of drying or extraction, standardizing the ginger essential oil according to main component and other main biological compounds is valuable, because the biological activity of ginger essential oil is depended on chemical components. The antibacterial, antifungal, analgesic, anti-inflammatory, anti-ulcer, immunomodulatory, relaxant, warming effects of ginger essential oil were confirmed in experimental and preclinical studies. The safety issue of ginger essential oil is well documented and is generally regarded as safe.

Due to the high yield of ginger essential oil and wide biological effects of ginger essential oil, its use in herbal formulations should be considered in many different basis rather than aromatherapy.

\section{Abbreviations}

MDR: Multidrug-resistant; ODQ: Owestry disability questionnaire;

PMA: Phorbol 12-myristate 13-acetate; VAS: Visual analogue scale

\section{Acknowledgements}

The author is thankful from TabibDaru Pharmaceutical Company for its support.

\section{Funding}

The study was supported by TabibDaru Pharmaceutical Company, Kashan, Iran.

Availability of data and materials

Not applicable

\section{Authors' contributions}

MM is the sole author of this manuscript, who prepared, read and submitted the manuscript. The author read and approved the final manuscript.

\section{Ethics approval and consent to participate}

Not applicable

\section{Consent for publication}

Not applicable

\section{Competing interests}

The authors declare that they have no competing interests.

\section{Publisher's Note}

Springer Nature remains neutral with regard to jurisdictional claims in published maps and institutional affiliations.
Received: 16 October 2018 Accepted: 20 December 2018

Published online: 15 January 2019

\section{References}

1. Pakrashi SC, Ginger PA. A versatile healing herb. In: Vedams eBooks (P) Ltd; 2003.

2. Porkert M, Howson M, Ullmann C. Chinese medicine: William Morrow \& Co; 1988

3. Bhatt N, Waly MI, Essa MM, Ali A. Ginger: A functional herb. Food as Medicine. 2013:51-71.

4. Gogte VM. Ayurvedic pharmacology and therapeutic uses of medicinal plants. Dravyaganvigyan, I Edn. Mumbai: Bhartiya Vidya Bhavan; 2000.

5. Mbaveng A, Kuete V. Zingiber officinale. In: Medicinal Spices and Vegetables from Africa: Elsevier; 2017. p. 627-39.

6. Sharifi-Rad M, Varoni EM. Plants of the genus Zingiber as a source of bioactive phytochemicals: From tradition to pharmacy. 2017;22(12). https:// doi.org/10.3390/molecules22122145.

7. Ebrahimzadeh Attari V, Malek Mahdavi A, Javadivala Z, Mahluji S, Zununi Vahed S, Ostadrahimi A. A systematic review of the anti-obesity and weight lowering effect of ginger (Zingiber officinale Roscoe) and its mechanisms of action. Phytotherapy research : PTR. 2017; Epub ahead of print. https://doi. org/10.1002/ptr.5986.

8. Wang J, Ke W, Bao R, Hu X, Chen F. Beneficial effects of ginger Zingiber officinale Roscoe on obesity and metabolic syndrome: a review. Ann N Y Acad Sci. 2017;1398(1):83-98. https://doi.org/10.1111/nyas.13375.

9. Govindarajan VS. Ginger - Chemistry, technology and quality evaluation: Part I. CRC. Crit Rev. 1982;17.

10. Ekundayo O, Laakso I, Hiltunen R. Composition of ginger (Zingiber officinale roscoe) volatile oils from Nigeria. Flavour Fragrance J. 1988;3(2):85-90. https://doi.org/10.1002/ffj.2730030207.

11. Onyenekwe PC, Hashimoto S. The composition of the essential oil of dried Nigerian ginger (Zingiber officinale Roscoe). Eur Food Res Technol. 1999. 209(6):407-10. https://doi.org/10.1007/s002170050517.

12. Huang B, Wang G, Chu Z, Qin L. Effect of oven drying, microwave drying, and silica gel drying methods on the volatile components of ginger (Zingiber officinale Roscoe) by HS-SPME-GC-MS. Drying Technol. 2012;30(3): 248-55. https://doi.org/10.1080/07373937.2011.634976.

13. Chu-Chin C, Chi-Tand H. Gas chromatographic analysis of thermal degradation products of gingerol compounds in steam-distilled oil from ginger (Zingiber officinale Roscoe). J Chromatogr A. 1987;387:499-504.

14. Kubra IR, Rao LJM. Effect of microwave drying on the phytochemical composition of volatiles of ginger. Int. J. Food Sci. Technol. 2012;47(1):5360. https://doi.org/10.1111/j.1365-2621.2011.02806.x.

15. Ali BH, Blunden G, Tanira MO, Nemmar A. Some phytochemical, pharmacological and toxicological properties of ginger (Zingiber officinale Roscoe): a review of recent research. Food Chem Toxicol. 2008;46(2):409420. https://doi.org/10.1016/j.fct.2007.09.085

16. Variyar PS, Gholap AS, Thomas P. Effect of Y-irradiation on the volatile oil constituents of fresh ginger (Zingiber officinale) rhizome. Food Res Int. 1997; 30(1):41-3. https://doi.org/10.1016/S0963-9969(97)00010-0.

17. Kamaliroosta Z, Kamaliroosta L, Elhamirad A. Isolation and identification of ginger essential oil. J Food Biosci Technol. 2013;3:73-80.

18. Yamamoto-Ribeiro MM, Grespan R, Kohiyama CY, Ferreira FD, Mossini SA, Silva EL, et al. Effect of Zingiber officinale essential oil on Fusarium verticillioides and fumonisin production. Food Chem. 2013;141(3):3147-52. https://doi.org/10.1016/j.foodchem.2013.05.144.

19. Cornell DW, Jordan RA. Composition and distinctive volatile flavour characteristics of the essential oil from Australian-grown ginger (Zingiber officinale). J Sci Food Agric. 1971;22(2):93-5. https://doi.org/10.1002/jsfa.2740220213.

20. Ravi Kiran C, Chakka AK, Padmakumari Amma KP, Nirmala Menon A, Sree Kumar MM, Venugopalan W. Essential oil composition of fresh ginger cultivars from North-East India. J Essent Oil Res. 2013;25(5):380-7. https://doi. org/10.1080/10412905.2013.796496.

21. Raina VK, Kumar A, Aggarwal KK. Essential oil composition of ginger (Zingiber officinale Roscoe) rhizomes from different place in india. J Essent Oil Bear Plants. 2005;8(2):187-91. https://doi.org/10.1080/ 0972060X.2005.10643442.

22. Stoyanova A, Konakchiev A, Damyanova S, Stoilova I, Suu PT. Composition and antimicrobial activity of ginger essential oil from Vietnam. J Essent Oil Bear Plants. 2006;9(1):93-8. https://doi.org/10.1080/0972060X.2006.10643478.

23. Meliani A, Nair S, Bensoltane A. Cyto-biochemical and antimicrobial investigations on essential oil of Zingiber officinale Roscoe. J Essent Oil Bear Plants. 2014;17(6):1120-9. https://doi.org/10.1080/0972060X.2014.986540. 
24. Mesomo MC, Corazza ML, Ndiaye PM, Dalla Santa OR, Cardozo L, Scheer AP. Supercritical $\mathrm{CO}_{2}$ extracts and essential oil of ginger (Zingiber officinale R.) Chemical composition and antibacterial activity. J Supercrit Fluids. 2013; 80(Supplement C):44-9. https://doi.org/10.1016/j.supflu.2013.03.031.

25. Salea R, Veriansyah B, Tjandrawinata RR. Optimization and scale-up process for supercritical fluids extraction of ginger oil from Zingiber officinale var. Amarum. J Supercrit Fluids. 2017;120(Part 2):285-294. doi:https://doi.org/10 1016/j.supflu.2016.05.035

26. Jakribettu RP, Boloor R, Bhat HP, Thaliath A, Haniadka R, Rai MP, et al. Chapter 50 - Ginger (Zingiber officinale Rosc.) Oils A2 - Preedy, Victor R. Essential Oils in Food Preservation, Flavor and Safety. San Diego: Academic Press; 2016. p. 447-54

27. Jeena K, Liju VB, Kuttan R. Antioxidant, anti-inflammatory and antinociceptive activities of essential oil from ginger. Indian J Physiol Pharmacol. 2013:57(1):51-62.

28. Liu L, Shao W, Lin G. Microcalorimetry studies on the antimicrobial actions of volatile oil of dry ginger. J Therm Anal Calorim. 2012;107(2):831-5. https://doi.org/10.1007/s10973-011-1589-3.

29. Bellik Y. Total antioxidant activity and antimicrobial potency of the essential oil and oleoresin of Zingiber officinale Roscoe. Asia Pac J Trop Dis. 2014;4(1): 40-4. https://doi.org/10.1016/S2222-1808(14)60311-X.

30. Intorasoot A, Chornchoem P, Sookkhee S, Intorasoot S. Bactericidal activity of herbal volatile oil extracts against multidrug-resistant Acinetobacter baumannii. J Intercult Ethnopharmacol. 2017;6(2):218-22. https://doi.org/10. 5455/jice.20170411091159.

31. Horne D, Holm M, Oberg C, Chao S, Young DG. Antimicrobial effects of essential oils on Streptococcus pneumoniae. Journal of Essential Oil Research. 2001;13(5):387-92. https://doi.org/10.1080/10412905.2001.9712241.

32. Friedman M, Henika PR, Mandrell RE. Bactericidal activities of plant essential oils and some of their isolated constituents against Campylobacter jejuni, Escherichia coli, Listeria monocytogenes, and Salmonella enterica. J Food Prot. 2002;65(10):1545-60

33. Sharma M, Sharma R. Synergistic antifungal activity of Curcuma longa (turmeric) and Zingiber officinale (ginger) essential oils against dermatophyte infections. J Essent Oil Bear Plants. 2011;14(1):38-47. https://doi.org/10.1080/ 0972060X.2011.10643899.

34. Ali SE, El-Shaffey AA, Selim ME, El-massry KF, Sabry BA. Chemical profile, antioxidant, antifungal and antiaflatoxigenic activity of parsley and ginger volatile and non-volatile extracts. Journal of Biologically Active Products from Nature. 2011;1(1):81-96. https://doi.org/10.1080/22311866.2011.10719074.

35. Bellik Y, Benabdesselam F, Ayad A, Dahmani Z, Boukraa L, Nemmar A, et al Antioxidant activity of the essential oil and oleoresin of Zingiber officinale roscoe as affected by chemical environment. Int J Food Prop. 2013;16(6): 1304-13. https://doi.org/10.1080/10942912.2011.584257

36. Mangprayool T, Kupittayanant S, Chudapongse N. Participation of citral in the bronchodilatory effect of ginger oil and possible mechanism of action. Fitoterapia. 2013:89:68-73. https://doi.org/10.1016/j.fitote.2013.05.012.

37. Funk JL, Frye JB, Oyarzo JN, Chen J, Zhang H, Timmermann BN. Antiinflammatory effects of the essential oils of ginger (Zingiber officinale Roscoe) in experimental rheumatoid arthritis. PharmaNutrition. 2016;4(3): 123-31. https://doi.org/10.1016/j.phanu.2016.02.004.

38. Chiba N, Aiuchi T, Suzuki T, Mori T, Shibasaki M, Kawahito Y, et al. Comparison of antinociceptive and and anti-inflammatory/analgesic essential oils in experimental animal model. Jpn J Phram Iliat Care Sci. 2014; 7:63-70.

39. Yong-Liang J, Jun-Ming Z, Lin-Hui Z, Bao-Shan S, Meng-Jing B, Fen-fen L, et al. Analgesic and anti-inflammatory effects of ginger oil. Chinese Herbal Medicines. 2011:3(2):150-5.

40. Nogueira de Melo GA, Grespan R, Fonseca JP, Farinha TO, da Silva EL, Romero AL, et al. Inhibitory effects of ginger (Zingiber officinale Roscoe) essential oil on leukocyte migration in vivo and in vitro. J Nat Med. 2011; 65(1):241-6. https://doi.org/10.1007/s11418-010-0479-5.

41. Sritoomma N, Moyle W, Cooke M, O'Dwyer S. The effectiveness of Swedish massage with aromatic ginger oil in treating chronic low back pain in older adults: a randomized controlled trial. Complement Ther Med. 2014;22(1):26-33. https://doi.org/10.1016/j.ctim.2013.11.002

42. Yip YB, Tam AC. An experimental study on the effectiveness of massage with aromatic ginger and orange essential oil for moderate-to-severe knee pain among the elderly in Hong Kong. Complement Ther Med. 2008;16(3): 131-8. https://doi.org/10.1016/j.ctim.2007.12.003.
43. Lee Y. Cytotoxicity evaluation of essential oil and its component from Zingiber officinale Roscoe. Toxicolo Res. 2016;32(3):225-30. https://doi.org/10. 5487/tr.2016.32.3.225.

44. Santos PASR, Avanço GB, Nerilo SB, RIA M, et al. Assessment of cytotoxic activity of rosemary (Rosmarinus officinalis L.), turmeric (Curcuma longa L.), and ginger (Zingiber officinale R.) essential oils in cervical cancer cells (HeLa). Sci World J. 2016;2016(8). https://doi.org/10.1155/2016/9273078.

45. Banerjee S, Sharma R, Kale RK, Rao AR. Influence of certain essential oils on carcinogen-metabolizing enzymes and acid-soluble sulfhydryls in mouse liver. Nutr Cancer. 1994;21(3):263-9. https://doi.org/10.1080/ 01635589409514324

46. Khushtar M, Kumar V, Javed K, Bhandari U. Protective effect of ginger oil on aspirin and pylorus ligation-induced gastric ulcer model in rats. Indian J Pharm Sci. 2009;71(5):554-8. https://doi.org/10.4103/0250-474x.58195.

47. Rashidian A, Mehrzadi S, Ghannadi AR, Mahzooni P, Sadr S, Minaiyan M. Protective effect of ginger volatile oil against acetic acid-induced colitis in rats: a light microscopic evaluation. J Integr Med. 2014;12(2):115-20. https:// doi.org/10.1016/s2095-4964(14)60011-X.

48. Zhou HL, Deng YM, Xie QM. The modulatory effects of the volatile oil of ginger on the cellular immune response in vitro and in vivo in mice. $J$ Ethnopharmacol. 2006;105(1-2):301-5. https://doi.org/10.1016/j.jep.2005.10.022.

49. Geiger JL. The essential oil of ginger, Zingiber officinale, and anaesthesia. Int J Aromather. 2005;15(1):7-14. https://doi.org/10.1016/j.ijat.2004.12.002.

50. Lete I, Allué J. The Effectiveness of Ginger in the Prevention of Nausea and Vomiting during Pregnancy and Chemotherapy. Integr Med Insights. 2016; 11:11-7. https://doi.org/10.4137/IMI.S36273.

51. Kawai T, Kinoshita K, Koyama K, Takahashi K. Anti-emetic principles of Magnolia obovata bark and Zingiber officinale rhizome. Planta medica. 1994; 60(1):17-20. https://doi.org/10.1055/s-2006-959399.

52. Huang Q, Matsuda H, Sakai K, Yamahara J, Tamai Y. The effect of ginger on serotonin induced hypothermia and diarrhea. Yakugaku zasshi. 1990;110(12): 936-42.

53. Onogi T, Minami M, Kuraishi Y, Satoh M. Capsaicin-like effect of (6)-shogaol on substance P-containing primary afferents of rats: A possible mechanism of its analgesic action. Neuropharmacology. 1992;31(11):1165-9. https://doi. org/10.1016/0028-3908(92)90013-F.

54. Vishwakarma SL, Pal SC, Kasture VS, Kasture SB. Anxiolytic and antiemetic activity of Zingiber officinale. Phytother Res. 2002;16(7):621-6. https://doi.org/ 10.1002/ptr.948.

55. Babarinde SA, Sunnie-Ododo MO, Akanbi WB, Oyegoke OO, Tijani R, Olaobaju SF. Comparative susceptibility of two developmental stages of hide beetle (Dermestes maculatus Degeer, 1774) to ginger (Zingiber officinale Roscoe) essential oil. J Saudi Soc Agric Sci. 2016. https://doi.org/10.1016/j. jssas.2016.09.003.

56. Opdyke DLJ. Ginger oil Monographs on Fragrance Raw Materials. Pergamon; 1979. p. 411.

57. Zubillaga MS, Bressan E, Lavad RS. Heavy metal mobility in polluted soils: effect of different treatments. Am J Environ Sci. 2008:4(6):620-4. https://doi. org/10.3844/ajessp.2008.620.624.

58. Jeena K, Liju VB, Kuttan R. A preliminary 13-week oral toxicity study of ginger oil in male and female Wistar rats. Int J Toxicol. 2011;30(6):662-70. https://doi.org/10.1177/1091581811419023.

59. Iwami M, Shiina T, Hirayama H, Shima T, Takewaki T, Shimizu Y. Inhibitory effects of zingerone, a pungent component of Zingiber officinale Roscoe, on colonic motility in rats. J Nat Med. 2011;65(1):89-94. https://doi.org/10.1007/ s11418-010-0463-0.

60. Romm A. Botanical medicine for women's health. Churchill Livingstone/ Elsevier St. Louis. In: Mo; 2010. 